\title{
KEMAMPUAN GURU SEKOLAH DASAR DALAM MENERAPKAN PEMBELAJARAN TEMATIK DI SEKOLAH
}

\author{
Munasik \\ Universitas Terbuka UPBJJ-UT Pangkalpinang \\ munasik@ut.ac.id
}

\begin{abstract}
Integrated thematic learning is learning that uses the theme to associate some subjects that can provide meaningful experiences and provide benefits for students. This study aims to determine the perception of lower grade elementary school teachers towards the implementation of thematic learning in learning; constraints faced by teachers in developing lesson plans, selecting media, and choose appropriate learning methods that can improve student learning outcomes. This study used a qualitative approach. Data collection techniques such as questionnaires, observation, interviews, documentation, which is used to study the problems in the thematic learning in low-grade elementary school. These results indicate that teachers' understanding and knowledge of thematic learning is good enough. Integrated learning is an instructional model that is most suitable for lowgrade primary school students, because the thematic learning / integrated, the child may be invited to participate actively in exploring the topics or events. The difficulty is in the preparation and implementation of the lesson plan is still encountering many obstacles, especially in the search for methods and media to suit all themes, while determining the success of the measuring instrument thematic learning (learning evaluation) that can accommodate some of the materials that are combined rather difficult to formulate. The way out is taken of teachers in the face of difficulties develop thematic learning circumvented by increasing discussions with colleagues and multiply by searching reference sources on the internet or other web.
\end{abstract}

Keywords: Teacher, thematic learning, thematic learning implementation, thematic lesson plan

\section{ABSTRAK}

Pembelajaran tematik adalah pembelajaran terpadu yang menggunakan tema untuk mengaitkan beberapa mata pelajaran sehingga dapat memberikan pengalaman yang bermakna serta memberikan keuntungan bagi siswa. Penelitian ini bertujuan untuk mengetahui persepsi guru SD kelas rendah terhadap penerapan pembelajaran tematik dalam pembelajaran; kendala yang dihadapi guru dalam mengembangkan RPP, memilih media, dan memilih metode pembelajaran yang tepat sehingga dapat meningkatkan hasil belajar siswa. Penelitian ini menggunakan pendekatan kualitatif. Teknik pengumpulan data berupa kuisioner, observasi, wawancara, dokumentasi, yang digunakan untuk mengkaji permasalahan dalam pembelajaran tematik di kelas rendah SD. Hasil penelitian ini menunjukan bahwa pemahaman dan pengetahuan guru tentang pembelajaran tematik sudah cukup baik. Pembelajaran terpadu merupakan suatu model pembelajaran yang paling sesuai untuk siswa SD kelas rendah, karena dalam pembelajaran tematik/terpadu, anak dapat diajak berpartisipasi aktif dalam mengeksplorasi topik atau kejadian. Kesulitannya adalah dalam penyusunan dan pengimplementasian rencana pelaksanaan pembelajaran masih menemui kendala terutama dalam mencari metode dan media yang sesuai dengan semua tema, sementara penentuan alat ukur keberhasilan pembelajaran tematik (evaluasi pembelajaran) yang bisa mengakomodir beberapa materi yang digabungkan agak sulit untuk dirumuskan. Jalan keluar yang diambil guru dalam menghadapi berbagai kesulitan 
mengembangkan pembelajaran tematik disiasati dengan memperbanyak diskusi dengan teman sejawat dan memperbanyak referensi dengan mencari sumber di internet atau web lainnya.

Kata Kunci: Guru, implementasi pembelajaran tematik, pembelajaran tematik, rencana pelaksanaan pembelajaran tematik

Pendidikan di Indonesia telah mengalami perubahan kurikulum secara berulangkali hingga tahun 2004 yang terkenal dengan Kurikulum Berbasis Kompetensi (KBK). Perubahan terakhir terjadi pada tahun 2006 yang disebut dengan Kurikulum Tingkat Satuan Pendidikan (KTSP). Kebijakan otonomi daerah telah memberikan kebebasan ruang gerak yang luas kepada lembaga pendidikan dalam mengelola sumber daya yang ada. Kebijakan tersebut memberikan keleluasaan kepada sekolah dalam mengalokasikan seluruh potensi dan prioritas sehingga mampu melakukan terobosanterobosan sistem pembelajaran yang lebih inovatif dan kreatif.

Salah satu upaya kreatif dalam melaksanakan pembelajaran di sekolah dasar adalah melakukan pembelajaran tematik khususnya pada kelas rendah. Pembelajaran model ini akan lebih menarik dan bermakna bagi anak karena model pembelajaran ini menyajikan tema-tema pembelajaran yang lebih aktual dan kontekstual dalam kehidupan sehari-hari. Namun demikian masih banyak pihak yang belum memahami dan mampu menerapkan model ini secara baik.

Panduan pembelajaran tematik dalam KTSP dari Depdiknas 2006 mengungkapkan bahwa pembelajaran tematik merupakan satu usaha untuk mengintegrasikan pengetahuan, keterampilan, nilai, atau sikap pembelajaran, serta pemikiran yang kreatif dengan menggunakan tema. Dari pernyataan tersebut dapat ditegaskan bahwa pembelajaran tematik dilakukan dengan maksud sebagai upaya untuk memperbaiki dan meningkatkan kualitas pendidikan, terutama untuk mengimbangi padatnya materi kurikulum. Di samping itu pembelajaran tematik akan memberi peluang pembelajaran terpadu yang lebih menekankan pada partisipasi/keterlibatan siswa dalam belajar. Keterpaduan dalam pembelajaran ini dapat dilihat dari aspek proses atau waktu, aspek kurikulum, dan aspek belajar mengajar.

Pembelajaran tematik menjadi sangat penting untuk diteliti, mengingat selain pembelajaran tematik mempunyai banyak kelebihan, namun juga mempunyai kekurangan khususnya bagi guru SD kelas rendah. Kesulitan tersebut terutama terjadi pada penerapan pembelajaran terpadu serta pemilihan tema, metode, dan media yang tepat. Oleh sebab itu untuk mewujudkan faktor-faktor tersebut perlu adanya persiapan yang mantap dari guru yang akan menerapkan pembelajaran tematik.

Pemahaman guru terhadap KTSP khusus pembelajaran tematik sudah baik. Hal tersebut terlihat dari jawaban benar responden mengenai pengertian KTSP yaitu 80\%. Mereka sudah memahami bahwa KTSP adalah seperangkat rencana dan pengaturan mengenai tujuan, isi dan bahan pelajaran, serta cara yang digunakan sebagai pedoman penyelenggaraan kegiatan pembelajaran untuk mencapai tujuan pendidikan tertentu, hal ini membuktikan bahwa tuntutan agar para guru dapat menguasai pembelajaran tematik dan berbagai kemampuan lainnya tercapai sudah. Kemampuan tersebut meliputi kemampuan dalam memahami konsep, merencanakan pengajaran, menuliskan tujuan pengajaran, menyajikan bahan pelajaran, memberikan pertanyaan kepada siswa, mengajarkan konsep, berkomunikasi dengan siswa, mengamati kelas, dan mengevaluasi hasil belajar (Cooper dalam Zahera, 1997).

Dalam proses pembelajaran tematik, aspek siswa menjadi perhatian utama, kegiatan belajar tidak lagi dimonopoli oleh guru (teacher centre) dan guru harus dapat menyajikan pembelajaran 
dengan menggunakan banyak metode, agar pembelajaran dapat berlangsung dengan efektif dan bermanfaat bagi siswa, maka metode yang dipilih harus dapat mengembangkan kreatifitas mereka seseuai dengan perkembangan serta kebutuhan peserta didik. Apabila dikaitkan dengan tingkat perkembangan anak, pembelajaran terpadu merupakan pendekatan pembelajaran yang memerhatikan dan menyesuaikan pemberian konsep sesuai dengan tingkat perkembangan anak. Pendekatan konsep sesuai dengan tingkat perkembangan anak yang berangkat dari teori pembelajaran yang menolak drill-system sebagai dasar pembentukan pengetahuan dan struktur intelektual anak (Depdikbud, dalam Prabowo. 2000).

Di samping itu pembelajaran tematik memiliki karakteristik yang berpihak kepada para siswa, sebagai berikut:

a. Berpusat pada siswa. Pembelajaran tematik berpusat pada siswa (student centered)

b. Pembelajaran tematik dapat memberikan pengalaman langsung kepada siswa (direct experiences).

c. Pemisahan matapelajaran tidak begitu jelas.

d. Menyajikan konsep dari berbagai matapelajaran dalam suatu proses pembelajaran.

e. Hasil pembelajaran sesuai dengan minat dan kebutuhan siswa.

f. Menggunakan prinsip belajar sambil bermain dan menyenangkan.

g. Pembelajaran tematik berpusat pada siswa (student centered).

h. Hasil pembelajaran sesuai dengan minat dan kebutuhan siswa.

i. Menggunakan prinsip belajar sambil bermain dan menyenangkan (Depdiknas, 2006).

Dari hasil penelitian ditemukan bahwa model pembelajaran tematik dilaksanakan melalui kerja keras dan berbagai usaha yang telah dilakukan guru dalam membelajarkan pembelajaran tematik walaupun banyak guru yang merasa kesulitan untuk mendapatkan media yang cocok dan bisa mewakili semua mata pelajaran yang dipadukan, serta mereka terlalu terpaku pada media pembelajaran yang sudah tersedia atau dapat dibeli. Sutirjo dan Sri Istuti Mamik (2004) menyebutkan bahwa pembelajaran tematik merupakan satu usaha untuk mengintegrasikan pengetahuan, keterampilan, nilai, atau sikap pembelajaran, serta pemikiran yang kreatif dengan menggunakan tema. Oleh sebab itu, semua pengalaman maupun kemampuan guru dalam mengembangkan pembelajaran tematik dan dengan segala aspeknya merupakan suatu keuntungan yang tidak terhingga bagi sekolah.

Pembelajaran tematik/terpadu merupakan suatu model pembelajaran yang memadukan beberpa materi pembelajaran dari berbagai standar kompetensi dan kompetensi dasar dari satu atau beberapa mata pelajaran. Penerapan pembelajaran ini dapat dilakukan melalui tiga pendekatan yakni: penentuan berdasarkan keterkaitan standar kompetensi dan kompetensi dasar, tema, dan masalah yang dihadapi. Tema diberikan dengan maksud menyatukan isi kurikulum dalam satu kesatuan yang utuh, memperkaya perbendaharaan bahasa anak didik dan membuat pembelajaran yang melibatkan beberapa mata pelajaran untuk memberikan pengalaman yang bermakna kepada siswa. Keterpaduan dalam pembelajaran ini dapat dilihat dari aspek proses atau waktu, aspek kurikulum, dan aspek belajar mengajar, dalam satu kali tatap muka.

Dalam rangka mengimplementasikan pogram pembelajaran yang sudah dituangkan di dalam silabus, guru harus menyusun Rencana Pelaksanaan Pembelajaran (RPP). RPP merupakan pegangan bagi guru dalam melaksanakan pembelajaran baik di kelas, laboratorium, dan/atau lapangan untuk setiap kompetensi dasar. Oleh karena itu, apa yang tertuang di dalam RPP memuat 
hal-hal yang langsung berkait dengan aktivitas pembelajaran dalam upaya pencapaian penguasaan suatu Kompetensi Dasar.

Standar Kompetensi adalah kualifikasi kemampuan peserta didik yang menggambarkan penguasaan pengetahuan, sikap, dan keterampilan yang diharapkan dicapai pada mata pelajaran tertentu. Standar kompetensi diambil dari Standar Isi (Standar Kompetensi dan Kompetensi Dasar). Kompetensi Dasar merupakan sejumlah kemampuan minimal yang harus dimiliki peserta didik dalam rangka menguasai SK mata pelajaran tertentu. Kompetensi Dasar dipilih dari yang tercantum dalam Standar Isi. Sebelum menentukan atau memilih Kompetensi Dasar, penyusun terlebih dahulu mengkaji standar kompetensi dan kompetensi dasar mata pelajaran dengan memperhatikan hal-hal sebagai berikut.

a. Urutan berdasarkan hierarki konsep disiplin ilmu dan/atau tingkat kesulitan Kompetensi Dasar

b. Keterkaitan antar standar kompetensi dan kompetensi dasar dalam mata pelajaran

c. Keterkaitan standar kompetensi dan kompetensi dasar antar mata pelajaran

d. Setelah tahap persiapan dilakukan, maka selanjutnya akan dipaparkan tahap pelaksanaan pembelajaran terpadu. Adapun tahap pelaksanaan pembelajarannya meliputi (Depdiknas 2006):

$>$ Kegiatan Pendahuluan/awal

Pada tahap ini dapat dilakukan panggilan terhadap anak tentang tema yang disajikan. Beberapa contoh kegiatan yang dapat dilakukan adalah, bercerita, kegiatan fisik/jasmani, dan menyanyi.

$>$ Kegiatan inti

Kegiatan inti difokuskan pada kegiatan-kegiatan yang bertujuan untuk pengembangan kemampuan baca, tulis hitung. Penyajian bahan pembelajaran dilakukan dengan menggunakan strategi/metode yang bervariasi dan dapat dilakukan secara klaksikal, kelompok kecil, ataupun perorangan.

$>$ Kegiatan penutup

Sifat dari kegiatan penutup adalah untuk menenangkan. Beberapa contoh kegiatan penutup yang dapat dilakukan adalah menyimpulkan atau mengungkapkan hasil pembelajaran yang telah dilakukan, mendongeng, membacakan cerita dari buku, pantomime, pesan-pesan moral, musik/apresiasi musik.

Langkah penting yang harus dipahami guru dalam kaitannya dengan KTSP tematik adalah bahwa guru harus mampu menjabarkan kompetensi dasar ke dalam indikator kompetensi yang siap dijadikan pedoman pembelajaran. Pada dasarnya pengembangan RPP tematik dan RPP bukan tematik hampir sama, perbedaan keduanya hanya terletak pada tema/topik dan pada kelas penerapannya. Apa yang tertuang didalam RPP memuat hal-hal yang langsung terkait dengan aktivitas pembelajaran dalam upaya pencapaian penguasaan suatu Kompetensi Dasar. UU No. 20 Tahun 2003 tentang Sistem Pendidikan Nasional menyatakan bahwa setiap peserta didik pada setiap satuan pendidikan berhak mendapatkan pelayanan pendidikan sesuai dengan bakat, minat, dan kemampuannya (Bab V Pasal 1-b).Oleh karena itu khususnya guru SD kelas rendah dalam merancang RPP harus menyesuaikan karakteristik anak usia SD kelas rendah. Komponenkomponen penting dalam RPP seperti media, metode, dan sumber belajar harus disesuaikan dengan kebutuhan anak. 


\section{METODE}

Penelitian ini menggunakan metode deskriptif kualitatif. Pengumpulan data dilakukan dengan kuesioner, observasi, wawancara, dan dokumentasi. Berdasarkan data yang diperoleh dari kuesioner, dilakukan tindak lanjut melalui wawancara langsung dengan para guru ditempat mereka mengajar, untuk memverifikasi dan mengelaborasi data tersebut, serta melakukan studi dokumentasi terhadap RPP yang telah disusun oleh guru.

Populasi dalam penelitian ini adalah guru SD di Provinsi Bangka Belitung. Sementara sebagai sampel adalah guru SD di wilayah Pulau Bangka. Pengambilan sampel penelitian dilakukan dengan teknik proposional random sampling sebanyak 10\% dari populasi penelitian.

\section{HASIL DAN PEMBAHASAN}

Pemahaman guru terhadap RPP khusus pembelajaran tematik sudah baik. Hal ini terlihat dari jawaban benar responden sebesar 80\% mengenai pengertian RPP. Berarti para guru sudah memahami bahwa RPP adalah seperangkat rencana dan pengaturan mengenai tujuan, isi dan bahan pelajaran, serta cara yang digunakan sebagai pedoman penyelenggaraan kegiatan pembelajaran untuk mencapai tujuan pendidikan tertentu.

Pada pertanyaan berkaitan dengan pemahaman guru terhadap pembelajaran terpadu, umumnya reponden menyatakan sangat setuju bahwa Pembelajaran terpadu merupakan suatu model pembelajaran yang paling sesuai untuk siswa SD kelas rendah. Dalam pembelajaran terpadu, anak dapat diajak berpartisipasi aktif dalam mengeksplorasi topik atau kejadian. Pembelajaran terpadu sangat memperhatikan kebutuhan anak sesuai dengan perkembangannya yang holistik dengan melibatkan secara aktif dalam proses pembelajaran baik fisik maupun emosionalnya. Pembelajaran Terpadu memadukan berbagai jenis keterampilan, sikap, atau kemampuankemampuan anak sehingga pembelajaran lebih bermakna.

Pembelajaran tematik atau disebut juga pembelajaran terpadu adalah suatu pendekatan pembelajaran yang melibatkan beberapa mata pelajaran untuk memberikan pengalaman yang bermakna kepada siswa. Bermakna dalam arti siswa akan memahami konsep-konsep yang mereka pelajari melalui pengalaman langsung dan menghubungkannya dengan konsep lain yang sudah mereka pahami. Hal tersebut sejalan dengan pernyataan Hernawan (2009) yang mengungkapkan bahwa pembelajaran tematik adalah pembelajaran yang berajak dari suatu tema tertentu sebagai pusat perhatian (center of interest) yang digunakan untuk memahami gejala-gejala dan konsep lain, baik yang berasal dari mata pelajaran yang bersangkutan maupun dari mata pelajaran lainnya.

Pemahaman bahwa pelaksanaan pembelajaran di SD kelas rendah yang terpisah untuk setiap mata pelajaran, dapat menyebabkan cara berpikir holistik siswa menjadi kurang berkembang. Pemahaman tentang kegiatan pemetaan tema dilakukan untuk memperoleh gambaran secara menyeluruh dan utuh semua standar kompetensi, kompetensi dasar dan indikator dari berbagai mata pelajaran yang dipadukan dalam tema yang dipilih, sudah menjadi bagian yang tidak terlepaskan pada pembelajaran tematik sudah dipahami guru.

Akan tetapi ditemukan kendala model pembelajaran tematik ini di kalangan guru SD, yaitu sulitnya untuk mendapatkan media yang cocok dan bisa mewakili kesemua mata pelajaran yang dipadukan. Dari hasil wawancara, mereka terlalu terpaku kepada media pembelajaran yang sudah tersedia atau dapat dibeli. Kreatifitas mereka kurang dalam mengembangkan media yang terdapat di lingkungan sekitar yang dapt dijadika media dalam pembelajaran tematik. Hal ini tidak sejalan 
dengan pendapat yang dikemukakan oleh Cooper (dalam Zahera, 1997) yang mengatakan bahwa seorang guru selayaknya mempunyai kemampuan tambahan selain kemampuannya dalam memahami konsep. Guru harus memiliki kemampuan merencanakan pengajaran, menuliskan tujuan pengajaran, menyajikan bahan pelajaran, memberikan pertanyaan kepada siswa, mengajarkan konsep, berkomunikasi dengan siswa, mengamati kelas, dan mengevaluasi hasil belajar.

Proses pembelajaran tematik sangat menuntut kreatifitas guru dalam memilih dan mengembangkan tema pembelajaran, serta menyorotinya dari barbagai aspek. Jika pendekatan tematik dilakukan oleh seorang guru, maka guru harus memiliki pemahaman yang luas tentang tema yang dipilih dalam kaitannya dengan berbagai mata pelajaran. Pembelajaran yang dilakukan oleh beberapa orang guru menuntut kekompakan dalam membentuk pemahaman, kompetensi, dan pribadi peserta didik. Tema yang dipilih hendaknya diangkat dari lingkungan kehidupan peserta didik, agar pembelajaran menjadi hidup.

Berdasarkan hasil survei yang dilakukan tentang penerapan RPP tematik dalam pembelajaran, $67 \%$ dari responden setuju bahwa pembelajaran dengan model tematik sangat cocok untuk diterapkan pada siswa kelas rendah. Selanjutnya $46 \%$ responden menyatakan bahwa kesulitan yang dihadapi guru akan bertambah apabila proses pembelajaran dilakukan dengan cara memisahkan bidang studi. Selain itu, sebanyak $80 \%$ responden kurang setuju dengan diberikannya kewenangan kepada sekolah dan satuan pendidikan untuk mengembangkan pembelajaran sesuai dengan kondisi dan kebutuhan peserta didik.

Persepsi terhadap RPP tematik dari masing-masing guru SD kelas rendah akan berbedabeda sesuai dengan pengetahuan dan keterampilan. Hal ini diakibatkan karena mengajar bukan hanya menyampaikan materi pelajaran saja, akan tetapi merupakan pekerjaan yang bertujuan dan bersifat kompleks. Oleh karena itu, dalam proses pembelajaran, diperlukan sejumlah keterampilan khusus yang didasarkan pada konsep dan ilmu pengetahuan yang spesifik.

Agar dapat melaksanakan tugasnya dengan baik, guru SD kelas rendah harus memiliki keahlian sesuai dengan bidangnya. Selain itu, diperlukan kemampuan dan pemahaman tentang pengetahuan dan keterampilan yang lain, misalnya pemahaman tentang psikologi perkembangan anak, pemahaman tentang teori-teori tingkah laku anak, kemampuan merancang dan memanfaatkan berbagai media dan sumber belajar, kemampuan mendesain strategi pembelajaran yamg tepat (metode), kemampuan mengembangkan RPP, dan mampu mengembangkan bahan evaluasi. Hal ini sesuai dengan pendapat Uno (2008: 85) yang mengemukakan bahwa desain pembelajaran dapat dijadikan titik awal dari upaya perbaikan kualitas pembelajaran.

Proses pembelajaran pada satuan pendidikan sekolah dasar harus memperhatikan karakteristik anak (siswa). RPP harus dirancang secara tepat karena akan berpengaruh terhadap kebermaknaan pengalaman belajar anak. Pengalaman belajar yang menunjukkan kaitan unsur-unsur konseptual baik di dalam maupun antar mata pelajaran akan memberi peluang terjadinya pembelajaran yang efektif dan lebih bermakna (meaningful learning). Oleh sebab itu, guru SD kelas rendah khususnya, dituntut untuk memiliki kemampuan untuk merancang dan melaksanakan proses pembelajaran tematik.

Berdasarkan hasil survei dan wawancara yang dilakukan terhadap guru tentang kendala yang dihadapi guru dalam mengembangkan RPP, sebanyak $80 \%$ responden menyatakan mengalami kesulitan dalam mengembangkan RPP tematik. Untuk mengatasi kendala ini, mereka membuat RPP secara berkelompok dalam gugus kelompok kerja guru (KKG). Selain itu, untuk mengatasi kesulitan tersebut mereka mengadopsi beberapa materi pembelajaran tematik yang ada di internet. 
Selanjutnya, sebanyak 65\% responden menyatakan mengalami kesulitan dalam menentukan jenjang kemampuan pada saat menyusun soal evaluasi. Kesulitan lain yang mereka alami adalah menentukan media yang paling tepat dalam pembelajaran tematik. Berdasarkan hasil wawancara, solusi yang ditempuh para responden dalam memecahkan permasalahan tersebut adalah dengan cara berdiskusi dengan teman sejawat. Hal ini sejalan dengan pendapat Theofilus (2006) yang mengatakan bahwa guru selama ini lemah dalam menyusun silabus dan rencana pelaksanaan pembelajaran (RPP) yang menjadi pedoman pada saat pembelajaran di kelas. Bahkan ada sebagian guru yang sama sekali tidak menyusun RPP, padahal kualitas rencana pelaksanaan pembelajaran sangat menentukan hasil kegiatan belajar mengajar.

Komponen penting lain dalam RPP adalah metode. Metode dalam pembelajaran tematik harus juga mempertimbangkan karakteristik anak usia SD kelas rendah yang berada tahap operasional konkrit. Metode mengajar sebaiknya yang bervariasi dan dapat dilakukan secara klaksikal, kelompok kecil, ataupun perorangan dengan menggunakan sumber belajar yang konkrit. Pembelajaran yang dilakukan perlu disiapkan berbagai variasi kegiatan dengan menggunakan multi metode, misalnya percobaan, bermain peran, tanya jawab, demonstrasi, dan bercakap-cakap. Namun dalam penerapannya di lapangan masih banyak kendala.

Hal ini sesuai dengan hasil penelitian yang dilakukan Sholichah (2011) yang mengemukakan bahwa guru kelas II SDN Purwosari II Pasuruan mengalami permasalahan dalam hal menganalisis kurikulum menjadi silabus tematik yang bertemakan lingkungan. Permasalahan lain ditemukan pada saat menyusun RPP tematik yang bertemakan lingkungan, kemudian mengimplementasikan, dan memberikan penilaian dalam pembelajaran tematik yang bertemakan lingkungan.

Penelitian lainnya dilakukan Rosadi (2009) tentang studi kasus pelaksanaan pembelajaran tematik di kelas II SDN Mergosono I kota Malang. Hasil penelitian menyatakan bahwa: 1) guru-guru kelas II SDN Mergosono I kota Malang mengalami lesulitan dalam menyusun RPP; 2) pembelajaran tematik di kelas II SDN Mergosono I Kota Malang, belum dilaksanakan secara optimal; 3) guru masih menilai peserta didik berdasarkan mata pelajaran, sehingga hasil belajar melalui pembelajaran tematik masih belum nampak.

Selanjutnya,hasil penelitian tersebut menyatakan bahwa terdapat beberapa hambatan yang dialami guru dalam pembelajaran tematik seperti: (a) kurikulum yang tidak dikemas dalam bentuk tematik; (b) penilaian hasil belajar tetap dalam bentuk penilaian per bidang studi/ mata pelajaran; (c) Kepala sekolah dan Penilik/Pengawas sekolah lebih mengambil kebijakan untuk pencapaian hasil belajar akhir program yang bersifat penilaian tiap mata pelajaran sehingga kurang memberikan perhatian pada pengembangan pembelajaran tematik.

Hasil survei tentang implikasi pembelajaran tematik terhadap guru, siswa, dan lainnya terhadap penerapan pembelajaran tematik di kelas menyatakan bahwa 65\% responden setuju dengan diberlakukannya standar nasional pendidikan (SNP). Hal ini berdampak pada pelaksanaan pembelajaran umumnya dan pembelajaran tematik khususnya, sehingga pada akhirnya semua guru harus pandai melaksanakan pengelolaan pembelajaran dengan baik dan benar. Sementara itu, 50\% reponden menyatakan kurang setuju apabila keberhasilan atau kegagalan implementasi kurikulum di sekolah sangat bergantung pada guru dan kepala sekolah. Menjaga kualitas peserta didik menjadi tanggungjawab bersama antara guru, kepala sekolah, orang tua/wali murid, murid itu sendiri, dan pemerintah.

Pembelajaran tematik lebih menekankan pada penerapan konsep belajar sambil melakukan sesuatu (learning by doing). Oleh karena itu, dalam membuat RPP guru perlu merancang dan mengemas pengalaman belajar yang bermakna bagi siswa. Pengalaman belajar yang berkaitan 
dengan kehidupan nyata (konseptual) menjadikan proses pembelajaran lebih efektif. Kaitan konseptual antar mata pelajaran yang dipelajari akan membentuk skema, sehingga siswa akan memperoleh keutuhan dan kebulatan pengetahuan. Selain itu, penerapan pembelajaran tematik di sekolah dasar sangat membantu siswa, karena sesuai dengan tahap perkembangan siswa yang masih melihat segala sesuatu sebagai satu keutuhan.

Pembelajaran tematik lebih menekankan pada keterlibatan siswa dalam proses belajar secara aktif. Untuk hal ini, sebanyak $90 \%$ responden menyatakan setuju bahwa melalui pembelajaran tematik, pemahaman siswa terhadap materi pelajaran menjadi meningkat dan tidak membuat siswa menjadi hanya duduk, dengar, catat, dan hafal (DDCH). Melalui pengalaman langsung siswa akan memahami konsep-konsep yang mereka pelajari dan mampu menghubungkannya dengan konsep lain yang telah dipahami.

Pembelajaran dengan menggunakan berbagai pendekatan, strategi dan metode diharapkan dapat memberi kemungkinan siswa mendapat pelayanan yang bersifat perbaikan, pengayaan, dan/atau percepatan sesuai dengan potensi, tahap perkembangan, dan kondisi siswa dengan tetap memperhatikan keterpaduan pengembangan pribadi siswa yang berdimensi ketuhanan, keindividuan, kesosialan, dan moral.

\section{KESIMPULAN}

Berdasarkan pemahaman guru terhadap KTSP khususnya pembelajaran tematik sudah baik (80\%), sementara persepsi guru SD kelas rendah terhadap RPP tematik berbeda-beda sesuai dengan pengetahuan dan keterampilan masing-masing guru. Pembelajaran tematik memiliki kendala yaitu apabila guru tidak bersikap kreatif dalam memilih dan mengembangkan tema pembelajaran, tidak memiliki pemahaman yang luas tentang tema yang dipilih dalam kaitannya dengan berbagai mata pelajaran, dan tidak kompak dalam melakukan pembelajaran, maka pembelajaran tematik tidak akan berjalan dengan baik.

Hasil ini sesuai dengan KTSP 2006 khusus pembelajaran tematik di ungkapkan bahwa dalam penerapannya mempunyai implikasi terhadap semua pihak yang terkait. Bagi guru, harus kreatif baik dalam menyiapkan kegiatan/pengalaman belajar bagi anak, dalam memilih kompetensi dari berbagai mata pelajaran dan mengaturnya agar pembelajaran menjadi lebih bermakna, menarik, menyenangkan dan utuh. Bagi siswa, harus siap mengikuti kegiatan pembelajaran yang dalam pelaksanaannya memungkinkan siswa bekerja secara individual, berpasangan, kelompok kecil, maupun klasikal.

Walaupun pembelajaran tematik memiliki beberapa keunggulan, namun perlu diperhatikan juga kelemahan-kelemahan dari tematik tersebut, seperti: (a) penerapan pembelajaran tematik harus disertai dengan pemilihan media, dan metode yang tepat dan sesuai, (b) guru harus benar-benar dapat menggabungkan sejumlah konsep dalam beberapa mata pelajaran yang berbeda, (c) guru harus memahami konsep pembelajaran bermakna dan pembelajaran terpadu sehingga penerapan tematik sesuai dengan tuntutan kurikulum. Oleh sebab itu, bagi para guru yang mengajar di kelas rendah, harus benar-benar memahami konsep dan karakteristik dari pembelajaran tematik, serta dapat menguasai konsep materi pelajaran yang telah digabung. 


\section{REFERENSI}

Badan Standar Nasional Pendidikan. (2006). Model kurikulum tingkat satuan pendidikan dan model silabus mata pelajaran SD/MI. Jakarta: BP. Cipta Jaya.

Direktorat Jendral Pendidikan Tinggi Depenas. (2008). Pembelajaran inovatif \& partisipasif. Jakarta: Direktorat Ketenagaan Ditjen Dikti Departemen Pendidikan Nasional.

Hernawan, A. H., Novi, R. (2009). Konsep dasar dan model-model pembelajaran terpadu. Jakarta: Universitas Terbuka.

Lyle, M., Spencer and Signe M., Spencer. (1993). Competence at work, models for superior performance. Canada: John Willey \& Sons, Inc.

Moleong, L. (1996). Penelitian kualitatif. Bandung: PT Remaja Rosdakarya

Mulyasa, E. (2005). Menjadi guru profesional menciptakan pembelajaran kreatif dan menyenangkan. Bandung: Remaja Rosda Karya.

Mulyasa, E. (2009). Kurikulum tingkat satuan pendidikan. Bandung: PT Remaja Rosdakarya.

Rosadi, I. (2009). Pelaksanaan pembelajaran tematik studi kasus di kelas II SDN Mergosono I Kota Malang. Skripsi, Program Studi S1 PGSD Jurusan KSDP Fakultas IImu Pendidikan Universitas Negeri Malang. http://karya-ilmiah.um.ac.id/index.php/KSDP/article/view/4310

Sholichah, M. (2011). Hasil penelitian, Skripsi (Sarjana)--Universitas Negeri Malang 2011, http://library.um.ac.id/free-contents/index.php/pub/detail/masalah-masalah-pembelajarantematik-tema-lingkungan-di-kelas-II-SDN-Purwosari-II-Pasuruan-maratus-sholichah48350.html

Sujana, N. (1990). Penilaian hasil proses belajar mengajar. Bandung: PT Rosdakarya.

Sukayati dan Wulandari, S. (2009). Pembelajaran tematik di SD. Departemen Pendidikan Nasional, Direktorat Jenderal Peningkatan Mutu Pendidik dan Tenaga Kependidikan. Pusat Pengembangan dan Pemberdayaan Pendidik dan Tenaga Kependidikan (PPPPTK) Matematika 2009.

Sukmadinata, S. N. (2005). Landasan psikologi proses pendidikan. Bandung: Remaja Rosda Karya. Suparman, A. (2004). Desain instruksional. Jakarta: Penerbit Universitas Terbuka.

Tim Pengembang PGSD dan S-2 Pendidikan Dasar. (1996/1997). Pembelajaran terpadu. Jakarta: Departemen Pendidikan dan Kebudayaan, Direktorat Jenderal Pendidikan Tinggi.

Walgito, B. (2003). Pengantar Psikologi Umum. Yogyakarta: Andi Offset.

Zahera. (1997) Definisi Kemampuan Guru dalam Mengajar. Diambil tanggal 29 April 2012 dari: http://blog.elearning.unesa.ac.id/tag/definisi-kemampuan-mengajar-guru. 